\title{
Burden of herpes zoster: the direct and comorbidity costs of herpes zoster events in hospitalized patients over 50 years in France
}

\author{
Cecile Blein ${ }^{1 *}$, Gaetan Gavazzi $^{2}$, Marc Paccalin $^{3}$, Charles Baptiste ${ }^{4}$, Gilles Berrut ${ }^{5}$ and Alexandre Vainchtock
}

\begin{abstract}
Background: The objectives of this study were to describe hospital stays related to $\mathrm{HZ}$ and to evaluate the direct and indirect cost of hospitalizations due to $\mathrm{HZ}$ among patients aged over 50 years.

Methods: The hospitalizations of people aged over 50 years were selected from the French national hospital 2011 database (PMSI) using ICD-10 diagnosis codes for HZ.

Firstly, stays with $\mathrm{HZ}$ as principal or related diagnostic were described through the patient characteristics, type of hospitalization and the related costs. Secondly, a retrospective case-control analysis was performed on stays with $\mathrm{HZ}$ as comorbidity in 5 main hospitalizations causes (circulatory, respiratory, osteo-articular, digestive systems and diabetes) to assess the impact of $\mathrm{HZ}$ as co-morbidity on the length of stay, mortality rate and costs.

Results: In the first analysis, 2,571 hospital stays were collected (60 \% of women, mean age: 76.3 years and mean LOS: 9.5 days). The total health assurance costs were 10,8 M€. Mean cost per hospital stay was 4,206€. In the second analysis, a significant difference in LOS and costs was shown when $\mathrm{HZ}$ was associated as comorbidity in other hospitalization's causes.

Conclusions: $\mathrm{HZ}$ directly impacts on the hospital cost. When present as comorbidity for other medical reasons, $\mathrm{HZ}$ significantly increases the length of hospital stay with subsequent economic burden for the French Health System.
\end{abstract}

Keywords: Herpes Zoster, Direct cost, Hospitalization, French, Indirect cost

\section{Background}

Herpes zoster (HZ), also called "shingles," results from reactivation of latent varicella-zoster virus (VZV), after a primo-infection known as "varicella" or "chickenpox". It spreads from a single ganglion to the neural tissue of the affected segment and the corresponding cutaneous dermatome [1].

If the reactivation is not contained, as can occur with age-related immunosenescence or iatrogenic immunosuppression, then viral replication ensues, resulting in ganglionitis, extensive infection, destruction of neurons and supporting cells [2]. This significant infection and associated inflammatory response is probably the origin of the prodromal pain that precedes the characteristic dermatomal eruption of HZ. Approximately $70 \%-80 \%$

\footnotetext{
* Correspondence: cblein@hevaweb.com

${ }^{1}$ HEVA, Lyon, France

Full list of author information is available at the end of the article
}

of patients with $\mathrm{HZ}$ describe prodromal pain in the dermatome where skin lesions subsequently appear. Prodromal pain may be constant or intermittent and frequent or sporadic, and it may or may not interfere with sleep. The rash associated with HZ has a brief erythematous and macular phase, which is often missed, after which papules rapidly appear. These papules develop into vesicles within 1-2 days, and vesicles continue to appear for 3-4 days [1].

Increasing age is the primary risk factor for herpes zoster. The disease usually occurs after 50 years of age, and approximately 60 percent of cases occur in women $[3,4]$.Other risk factors include human immunodeficiency virus infection, neoplasic diseases, organ transplantation, use of immunosuppressive drugs, and other conditions that cause a decline in cell-mediated immunity. Complications occur in almost $50 \%$ of older persons (60 years of age or older) with HZ [5-7]. Most frequent 
complications are persistent and neurological pain, named post-herpetic neuralgia (PHN), which concern $18 \%$ of adults with herpes zoster and $33 \%$ of those aged 79 and olders [8].

Herpes zoster ophthalmicus designates a localisation of herpes zoster with eye's involvement. Eyes complications are common in this case and result in considerable health care use and permanent vision decrement in about $6.6 \%$ of individual with $\mathrm{HZ}$ eyes involvement [9].

Throughout Europe, estimated annual $\mathrm{HZ}$ incidences range from 2.0 to 4.6/1,000 person-years (PY) with lower values in Iceland, Germany and Switzerland (around 2/ 1,000 PY) and higher in Belgium, Spain, Italy (around 4/ $1,000 \mathrm{PY}$ ) and globally concerning women. The incidence and severity of $\mathrm{HZ}$ increase with advancing age; more than half of all persons in whom HZ develops are older than 60 years [10-14]. HZ epidemiological data are annually estimated by the French sentinel surveillance reporting system (based on data derived from consultations of a sample of French GPs). Moreover, HZ can be a repetitive history: in contrast with previous assessments, rates of $\mathrm{HZ}$ recurrence appear to be comparable to rates of first occurrence in immunocompetent individuals [15].

In France, estimated $\mathrm{HZ}$ annual incidences were 346,988 cases in 2009 [16], 269,833 cases in 2010 [17], 219,823 cases in 2011 [18] and 303,625 cases in 2012 [19]. Based on the sentinel surveillance reporting system, Gonzalez Chiappe et al., estimated the French $2010 \mathrm{HZ}$ incidence rate to be 382 cases/100,000 inhabitants. The article also studies herpes zoster hospitalizations trough the PMSI database between 2000 and 2006. Over the seven years, 61,429 hospital stays were collected with a mean annual of 8,728 stays per year. The mean age observed was 72 years and mean LOS was 9.18 days [20].

The objectives of this study were to describe hospital stays related to $\mathrm{HZ}$ in 2011, and to evaluate the cost of hospitalizations due to $\mathrm{HZ}$ and the impact of zona as comorbidity on length of stay, death and cost in hospitalization for others diseases among patients aged over 50 years.

\section{Methods}

\section{Data sources}

The French Medical Information System (Programme de Médicalisation des Systèmes d'Information - PMSI) is an exhaustive medico-administrative hospital discharge database that covers all public and private hospitals in France as well as those in the French Territories [21-26]. Diagnoses identified during admission are coded using the International Classification of Diseases, 10th revision (ICD-10) by the physician. PMSI includes a compilation of standard discharge summaries ("Résumé Standard de Sortie", RSS) for every admission. Anonymised data ("Résumé Standardisé Anonymisé", RSA) with limited socio-demographic information (gender, age, residence code) and medical information on the main diagnosis that led to hospital admission, the nature of treatments received and examinations carried out, underlying comorbidities and possible complications, are made available for epidemiologic studies. Each patient's stay is classified by Diagnosis Related Group (DRG) (Groupe Homogène de Séjours) according to the information documented by the physician.

The economic burden of hospitalized cases would be expected to be well documented within the PMSI database because since the introduction of a DRGbased prospective payment system (the "Tarification à l'Activité") in 2005, the PMSI database has been used as the basis for the funding of services in all hospitals, with each hospital receiving DRG-based payments according to the national tariff. Thus, data extracted from this database is exhaustive (all public and private hospitals are included and no sampling is done) and of high quality, with limited coding errors.

\section{Data collection of herpes zoster}

All hospital stays with a primary, related and associated herpes zoster specific code were selected from the 2011 PMSI database using the ICD-10 codes B02* "'Zoster)". In order to evaluate the hospitalization economic impact of $\mathrm{HZ}$ among patients aged over 50 years in France and to assess the impact on death, hospitalization's length of stay and hospitalization's cost of HZ when this latter is comorbidity in other hospitalization's causes, two different data collection were done from the PMSI database.

For the first analysis, a conservative approach was done by selecting only those hospital stays that had a primary diagnosis or had direct link with $\mathrm{HZ}$ for patients aged over 50 years. HZ ICD 10 codes were selected based on Gonzalez Chiappe et al. in 2010 publication, by seven codes: B020 "HZ encephalitis", B021 "HZ meningitis", B022 "HZ with neurological disease", B023 "HZ Ophthalmicus", B027 "Disseminated HZ", B028 "HZ with other complications" and B029 "HZ with no complications" [20]. A physician manually assessed all hospital stay cases that have an associated link to $\mathrm{HZ}$ (i.e. where $\mathrm{HZ}$ was a secondary diagnosis) to exclude those where $\mathrm{HZ}$ was considered doubtful.

For patient's hospitalized for HZ, gender, age and comorbidities, type of management received (medical, surgical or exploratory), type of stay (conventional inpatient stays or short outpatient stays), and length of stay, type of $\mathrm{HZ}$, immunosuppression factors, hospital discharges and occurrence of related deaths were collected. Conventional inpatient stays include day hospitalizations defined as an admission of 2 or more days' duration, whereas short stays include day hospitalizations. Since patients may have several hospital stays 
during the year, the overall number of patients hospitalized at least once over a given period could be obtained by linking all hospital stays with anonymized patient identification numbers based on the patient's social security number, date of birth and gender.

For the second analysis, all hospital stays with an associated $\mathrm{HZ}$ diagnosis code were firstly selected. Then immunocompromised patients have been excluded. Codes of immunosuppressive conditions were D8* "Certain disorders involving the immune mechanism"; B20" "Human immunodeficiency virus [HIV] disease resulting in infectious and parasitic diseases" to B24* "Unspecified human immunodeficiency virus [HIV] disease". A disease approach was done by selecting only all the hospital stays in 5 main diseases where $\mathrm{HZ}$ is only a comorbidity diagnosis and not the reason for hospitalization. The first five reasons of hospitalizations observed with a $\mathrm{HZ}$ comorbidity were hospitalizations for circulatory system (14\%), hospitalizations for respiratory system (11\%), hospitalizations for osteo-articular system (6\%), hospitalizations for digestive systems $(6 \%)$ and hospitalizations for diabetes system (2\%).

For patients hospitalized for the 5 main diseases with HZ comorbidity, gender, age, were collected. A retrospective case-control was performed for each of the preselected 5 pathologies excluding hospital stays with at least an immunosuppression diagnosis. The cases were defined by hospitalizations with HZ in DAS and controls by cases-matched hospitalizations without HZ in DAS. Chi-square tests were done to compare the distribution of both genders and age between the two cohorts. A matching method based on age and sex was performed to neutralize confounding factors. Then median LOS, hospital mortality and costs were calculated for both selections and compared by statistical non-parametric analyses (Wilcoxon-Mann-Whitney) in each of the five categories.

\section{Economic burden of $\mathrm{HZ}$ hospitalization}

Costs were estimated from the social security payer perspective, i.e. Ministry of Health public fund. Ambulatory costs and indirect costs related to productivity loss were not considered in the present study. Hospitalassociated costs were calculated using official DRG tariffs for each year considered. DRG tariffs represent the willingness-to-pay by the national health insurance and not the hospital cost production. DRG tariffs include medical and related procedures, nursing care, treatments (except specific expensive drugs), food and accommodation, and investment costs for hospitalized patients. Additional cost per day of hospitalization in emergency or an intensive care unit was added to DRG tariffs, when appropriate. For private hospitals, physician's fees were also added to the DRG tariffs; physicians are reimbursed on a fee-for-service basis [source:
ENCC 2010]. Costs are presented as mean/median cost per stay, mean/median cost per patient and total cost per year for France. All costs are presented in actualized Euros (base year 2012).

\section{Ethics and consent}

This non-interventional study does not fall under the scope of the law and does not require any ethics committee submission (Law 88-1138 relative to Biomedical Research of December 20, 1988, modified on August 9, 2004). The ATIH (Agence Technique de l'Information sur l'Hospitalisation) is responsible for managing the finalized database each year under approval by the CNIL (National commission for data processing and civil liberties).

\section{Results}

\section{Burden of $\mathrm{HZ}$ hospitalization}

\section{Hospital stay characteristics}

A total number of 7,389 stays for $\mathrm{HZ}$ were identified in the PMSI 2011 database for patients aged over 50 years. A medical interpretation by a DIM physician classified the selection into 2 groups, 2,571 hospital stays (35\%), related to 2,392 patients, were directly related to $\mathrm{HZ}$ $(2,362$ and 209 stays were in public and private hospitals, respectively), and 4,818 stays (65\%) were indirectly related to HZ. This last group was excluded $(4,047$ and 771 stays were in public and private hospitals, respectively) [Fig. 1]. A conservative approach was taken by selecting only those hospital stays that had a primary diagnosis of $\mathrm{HZ}$ or had direct link with $\mathrm{HZ}$.

Over the 2,571 hospital stays observed during the study period for HZ, stays for B029 "HZ without complications" was mainly represented with 911 hospital stays (33.1\%). The following type of zona B023 "HZ Ophthalmicus", B028 "HZ with other complications", and B022 "HZ with neurological disease" represented between 450 and 487 stays ( $17.5 \%$ to $18.9 \%$ ). Others type of zona represented between 147 and 44 hospital stays [Table 1].

Sex ratios were equivalent in almost all $\mathrm{HZ}$ type. Women represented $60 \%$ of patients of the cases. We observed a different sex ratio only in the B027 "Disseminated HZ" type where the women represented $50 \%$ of patients.

Over the 2,392 patients included, the overall mean age was 76.3 years (SD 11.7) and the median age was 79 years (range 57) [Table 2]. The mean age was different between HZ types : 77.7 years (SD 11.1) for B028 "HZ with other complications", 77.3 years (SD 11.2) for B023 "HZ Ophthalmicus", 73.5 years (SD 12.1) for B027 "Disseminated HZ", 73.3 years (SD 11.7) for B021 "HZ meningitis" and 74.2 years (SD 12.2) for B020 "HZ encephalitis". Over the 2,392 patients, 444 patients $(18.6 \%)$ were aged $80-84$ years, 438 patients $(18.3 \%)$ were aged $85-89$ years, 339 


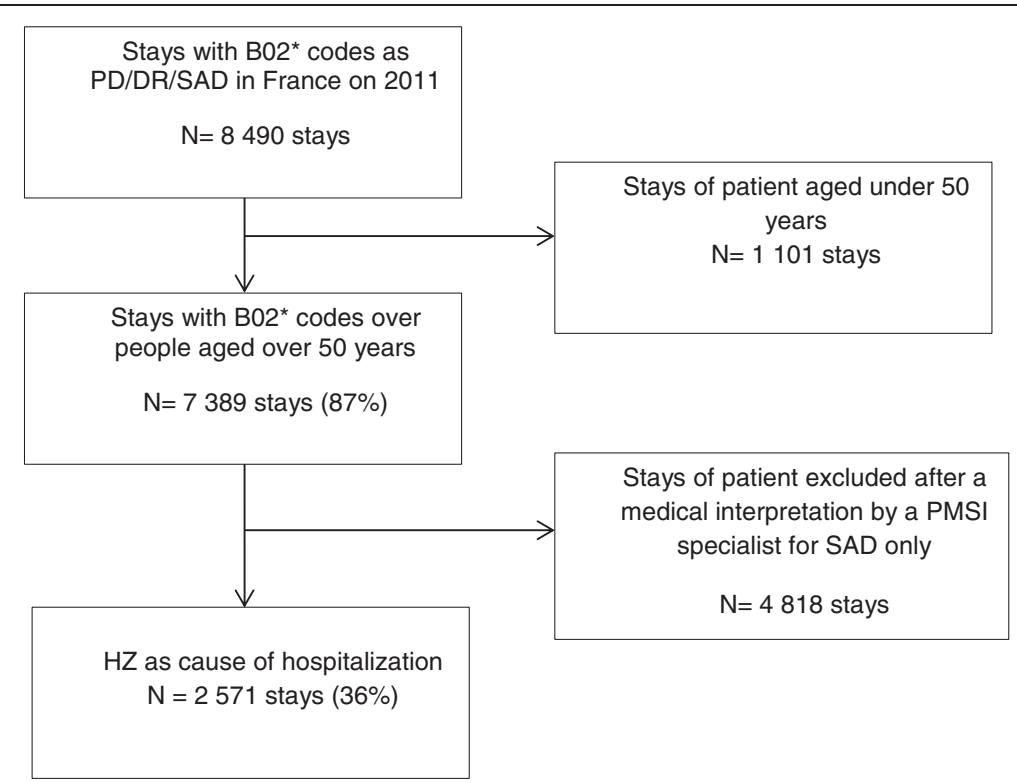

Fig. 1 Chart flow of study protocol of $\mathrm{HZ}$ as cause of hospitalization

Table 1 Hospital stays, LOS and means HZ Costs for Health Assurance ( $€$ )

\begin{tabular}{|c|c|c|c|c|c|c|c|c|}
\hline & $\begin{array}{l}\text { B020 "HZ } \\
\text { encephalitis" }\end{array}$ & $\begin{array}{l}\mathrm{B} 021 \text { "HZ } \\
\text { meningitis" }\end{array}$ & $\begin{array}{l}\text { B022 "HZ with } \\
\text { neurological }\end{array}$ & $\begin{array}{l}\text { B023 "HZ } \\
\text { Ophtalmicus" }\end{array}$ & $\begin{array}{l}\text { B027 } \\
\text { "Disseminate } \\
\text { d HZ" }\end{array}$ & $\begin{array}{l}\mathrm{B} 028 \text { "HZ } \\
\text { with other } \\
\text { complications }\end{array}$ & $\begin{array}{l}\text { B029 "HZ with no } \\
\text { complications }\end{array}$ & Total \\
\hline Public hospital stays & 59 & 42 & 407 & 463 & 136 & 417 & 838 & 2,362 \\
\hline Private hospital stays & 4 & 2 & 43 & 24 & 11 & 52 & 73 & 209 \\
\hline Total stays & 63 & 44 & 450 & 487 & 147 & 469 & 911 & 2,571 \\
\hline$\%$ stays & 2.5 & 1.7 & 17.5 & 18.9 & 5.7 & 18.2 & 35.4 & 100 \\
\hline LOS & 19.5 & 14.3 & 9.8 & 9.1 & 13.0 & 9.8 & 7.9 & 9.5 \\
\hline $\begin{array}{l}\text { Mean Costs per stay in } \\
\text { public hospital }\end{array}$ & $8,912 €$ & $5,122 €$ & $4,597 €$ & $3,587 €$ & $7,269 €$ & $4,848 €$ & $3,568 €$ & $4,350 €$ \\
\hline SD & $6,847 €$ & $3,143 €$ & $3,138 €$ & $2,112 €$ & $25,889 €$ & $2,592 €$ & $3,219 €$ & $6,963 €$ \\
\hline $\begin{array}{l}\text { Median Costs per stay } \\
\text { in public hospital }\end{array}$ & $8,304 €$ & $4,206 €$ & $3,819 €$ & $3,426 €$ & $5,205 €$ & $5,765 €$ & $3,702 €$ & $3,701 €$ \\
\hline Range & $38,302 €$ & $15,461 €$ & $20,375 €$ & $13,334 €$ & $302,233 €$ & $21,434 €$ & $77,402 €$ & $302,645 €$ \\
\hline $\begin{array}{l}\text { Mean Costs per stay in } \\
\text { private hospital }\end{array}$ & $8,605 €$ & $3,662 €$ & $3,139 €$ & $2,139 €$ & $2,187 €$ & $2,442 €$ & $2,471 €$ & $2,677 €$ \\
\hline SD & $4,698 €$ & $230 €$ & $1,880 €$ & $1,194 €$ & $1,248 €$ & $1,324 €$ & $1,785 €$ & $1,897 €$ \\
\hline $\begin{array}{l}\text { Median Costs per stay } \\
\text { in private hospital }\end{array}$ & $6,455 €$ & $3,662 €$ & $2,414 €$ & $2,367 €$ & $2,519 €$ & $2,519 €$ & $3,219 €$ & $2,519 €$ \\
\hline Range & $9,770 €$ & $325 €$ & $681 €$ & $4,962 €$ & $3,570 €$ & $5,868 €$ & $6,136 €$ & $15,341 €$ \\
\hline Mean Costs per stay & $8,893 €$ & $5,056 €$ & $4,458 €$ & $3,516 €$ & $6,888 €$ & $4,581 €$ & $3,480 €$ & $4,206 €$ \\
\hline SD & $6,703 €$ & $3,084 €$ & $3,069 €$ & $2,098 €$ & $24,932 €$ & $2,595 €$ & $3,142 €$ & $6,711 €$ \\
\hline Median Costs per stay & $8,304 €$ & $4,206 €$ & $3,819 €$ & $3,427 €$ & $3,869 €$ & $5,765 €$ & $3,702 €$ & $3,702 €$ \\
\hline Range & $38,032 €$ & $15,461 €$ & $20,375 €$ & $13,334 €$ & $302,484 €$ & $21,434 €$ & $77,402 €$ & $302,646 €$ \\
\hline Total Costs & $560,284 €$ & $222,465 €$ & $2,006,179 €$ & $1,697,544 €$ & $1,007,870 €$ & $2,148,890 €$ & $3,167,679 €$ & $\begin{array}{l}10,810,911 \\
€\end{array}$ \\
\hline $\begin{array}{l}\text { Proportion of the total } \\
\mathrm{HZ} \text { cost }\end{array}$ & $5 \%$ & $2 \%$ & $19 \%$ & $16 \%$ & $9 \%$ & $20 \%$ & $29 \%$ & $100 \%$ \\
\hline
\end{tabular}

HZ: Herpes Zoster, LOS: Length of stay, SD: Standard Deviation 
Table 2 Distribution of patients per age group and per $\mathrm{HZ}$ Code

\begin{tabular}{|c|c|c|c|c|c|c|c|c|c|}
\hline $\begin{array}{l}\text { Age } \\
\text { group }\end{array}$ & $\begin{array}{l}\text { B020 "HZ } \\
\text { encephalitis" }\end{array}$ & $\begin{array}{l}\mathrm{B} 021 \text { "HZ } \\
\text { meningitis" }\end{array}$ & $\begin{array}{l}\text { B022 "HZ with } \\
\text { neurological disease" }\end{array}$ & $\begin{array}{l}\text { B023 "HZ } \\
\text { Ophtalmicus" }\end{array}$ & $\begin{array}{l}\text { B027 } \\
\text { "Disseminated HZ" }\end{array}$ & $\begin{array}{l}\text { B028 "HZ with } \\
\text { other complications" }\end{array}$ & $\begin{array}{l}\text { B029 "HZ with no } \\
\text { complications" }\end{array}$ & Total & $\%$ \\
\hline $\begin{array}{l}50-54 \\
\text { years }\end{array}$ & 6 & 2 & 19 & 18 & 11 & 14 & 44 & 113 & 4.7 \\
\hline $\begin{array}{l}55-59 \\
\text { years }\end{array}$ & 4 & 7 & 32 & 22 & 16 & 24 & 69 & 171 & 7.1 \\
\hline $\begin{array}{l}60-64 \\
\text { years }\end{array}$ & 3 & 3 & 30 & 38 & 13 & 34 & 83 & 201 & 8.4 \\
\hline $\begin{array}{l}65-69 \\
\text { years }\end{array}$ & 8 & 5 & 34 & 30 & 14 & 30 & 81 & 193 & 8.1 \\
\hline $\begin{array}{l}70-74 \\
\text { years }\end{array}$ & 6 & 0 & 48 & 45 & 19 & 50 & 78 & 244 & 10.2 \\
\hline $\begin{array}{l}75-79 \\
\text { years }\end{array}$ & 9 & 7 & 64 & 75 & 17 & 73 & 105 & 339 & 14.2 \\
\hline $\begin{array}{l}80-84 \\
\text { years }\end{array}$ & 11 & 8 & 84 & 91 & 23 & 88 & 146 & 444 & 18.6 \\
\hline $\begin{array}{l}85-89 \\
\text { years }\end{array}$ & 12 & 8 & 75 & 84 & 25 & 83 & 161 & 438 & 18.3 \\
\hline $\begin{array}{l}90-94 \\
\text { years }\end{array}$ & 3 & 1 & 30 & 45 & 6 & 44 & 67 & 190 & 7.9 \\
\hline $\begin{array}{l}95 \text { years } \\
\text { and over }\end{array}$ & 0 & 0 & 6 & 12 & 2 & 13 & 29 & 61 & 2.5 \\
\hline $\begin{array}{l}\text { Total } \\
\text { (patients) }\end{array}$ & 62 & 41 & 422 & 460 & 146 & 453 & 863 & 2,392 & 100 \\
\hline $\begin{array}{l}\text { Mean } \\
\text { age } \\
\text { (years) }\end{array}$ & 74.2 & 73.3 & 76.1 & 77.3 & 73.5 & 77.7 & 75.9 & 76.3 & \\
\hline SD & 12.2 & 11.7 & 11.4 & 11.2 & 12.1 & 11.1 & 12.2 & 11.7 & \\
\hline $\begin{array}{l}\text { Median } \\
\text { age } \\
\text { (years) }\end{array}$ & 76,5 & 76 & 78 & 80 & 74 & 80 & 78 & 79 & \\
\hline Range & 43 & 39 & 52 & 57 & 47 & 52 & 51 & 57 & \\
\hline
\end{tabular}

HZ: Herpes Zoster, SD: Standard Deviation

patients (14.2\%) were aged 75-79 years, and 244 patients (10.2\%) were aged 70-74 years [Table 2]. Patients were mainly hospitalized once (95\%) during the study period of 1 year.

Public hospital represented $92 \%(2,362)$ of hospital stays [Table 1] and in nearly all hospital stays (97\%; 2,250), the illness was medically managed, with surgical intervention recorded in $<1 \%$ (30) of stays. More than half of stays (72\%; 1,859) had comorbidity. Circulatory system was the main co-morbidity with $41.7 \%(1,071)$, followed by endocrine system in $28.6 \%$ (735), nervous system in $21.0 \%$ (539) and malignancies in $14.6 \%$ (376). [Fig. 2] Diabetes, kidney diseases and respiratory system co-morbidity rates ranged from $10.8 \%$ (278) to $12.5 \%$ (321) and finally musculoskeletal system occurred in $0.6 \%$ (15). A patient may have several comorbidities within a stay, so the sum of different kinds of comorbidity stays does not give the total amount of stays. Of the 2,571 hospital stays, 81 (3.2 \%) stays presented immunosuppression treatments codes, ranging from $0.0 \%$ to $3.6 \%$ except for the code B027.
Conventional inpatient stays represented $44 \%(2,408$ stays) of all hospital stays. The mean length of hospital stays was 9.5 days (SD 11.22) and the median length of stay was 7 days (range from 0 to 385 days), ranging from 7.9 days (SD 7.46) for B029 "HZ without complications" to 19.5 days (SD 15.37) for B020 "HZ encephalitis" [Table 1].

A death rate of $1.6 \%$ (38 patients) was observed during the study, range $0.5 \%$ (5/911) for B029 "HZ without complications" to $7.9 \%(5 / 63)$ for B020 "HZ encephalitis" [Table 3]. Over the 38 deaths observed, only 1 death occurred among patients with no comorbidity although 37 deaths occurred among patients with at least one comorbidity.

Discharge from hospital to home occurred in 2,060/ 2,571 hospital stays (80.1\%) [Table 3]. Alternatively, 289 hospital stays (11.2\%) led to a transfer into another health care institution (173 stays in a Recovery after care and rehabilitation Center). Intra hospital transfer occurred in 184 hospital stays (7.2 \%) and led to an internal 


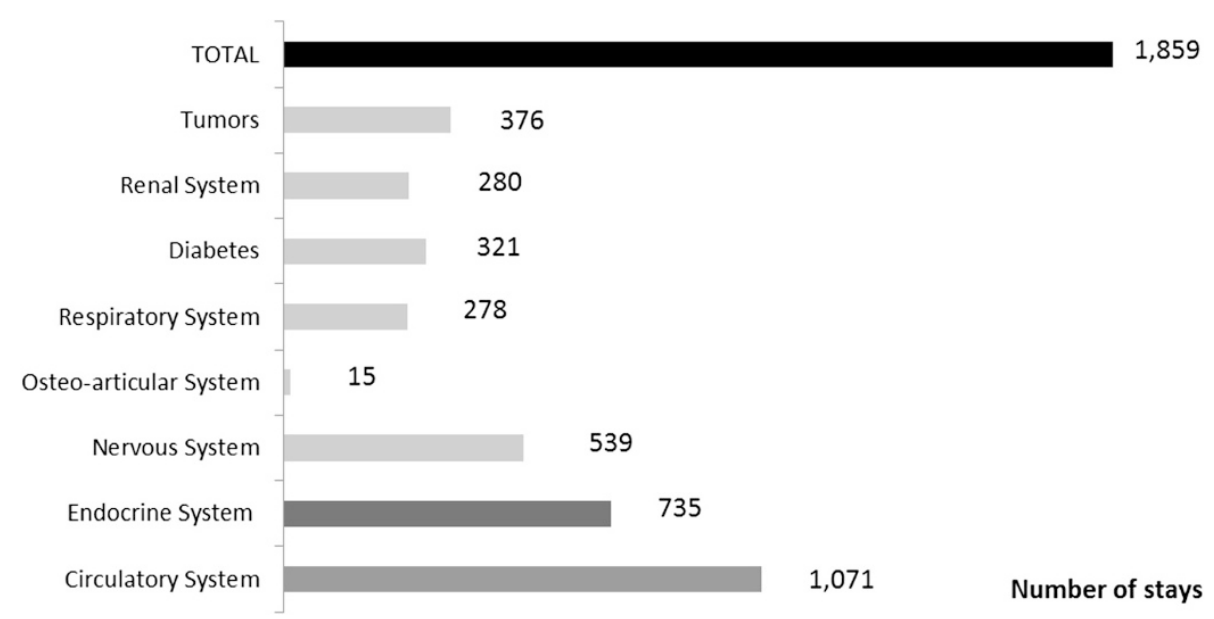

Fig. 2 Distribution of comorbidity in Zona hospital stays

transfer between units within the same hospital. The rate of discharge is very high for $\mathrm{HZ}$ except for the code B020 "HZ encephalitis" (31/63 stays or 49.2\%) and B021 "HZ meningitis" (28/44 stays or $63.6 \%)$ The latters have a higher rate of transfer to another health care institution with respectively $34.9 \%$ for B020 and $22.7 \%$ for B021 [Table 3].

Over the 2,571 stays, 2,446 hospital admissions (95 \%) from home patient were mainly observed. Among the 473 hospital discharges to transfer or mutation (289 transfers / 184 mutations), 419 hospital admissions (88 \%) from home patient were collected.

\section{Economic burden of $\mathrm{HZ}$ hospitalization}

Total HZ health insurance costs for the 2,571 hospital stays were estimated at responsible for $10,810,911 €$ [Table 1]. The mean costs for health insurance per hospital stay was $4,206 €$ (SD 6,211€) with a range from $4,350 €$ (SD 6,963€) for public hospital to $2,677 €$ (SD 1,897€) for private hospital. The mean cost per patient was $4,519 €$ (SD 6,905€) range to $4,653 €$ (SD 7,164€) for public hospital to $2,812 €$ (SD 1,888€) for private hospital.

The mean costs per hospital stay for $\mathrm{HZ}$ ranged from $8,893 €(S D$ 6,703€) for B020 "HZ encephalitis" to 3,480€ (SD 3,142€) for B029 "HZ without complications" [Table 1]. The total annual costs of B029 "HZ without complications" care were responsible for $29 \%$ of total $\mathrm{HZ}$ annual costs, B028 "HZ with other complications" for $20 \%$, B022 "HZ with neurological disease" for $19 \%$, B023 "HZ Ophthalmicus" for $16 \%$, B027 "Disseminated HZ" for $9 \%$, B020 "HZ encephalitis" for $5 \%$, and B021 "HZ meningitis" for $2 \%$ [Table 1].

\section{Impact of $\mathrm{HZ}$ comorbidity in hospitalizations for other reasons \\ Hospital stay characteristics}

A total number of 4,818 hospital stays with a zona comorbidity among patients aged over 50 years without

Table 3 Distribution

\begin{tabular}{|c|c|c|c|c|c|c|c|c|c|c|c|c|c|c|c|}
\hline & \multirow{2}{*}{\multicolumn{2}{|c|}{ Home }} & \multicolumn{8}{|c|}{ Transfered } & \multirow{2}{*}{\multicolumn{2}{|c|}{$\begin{array}{l}\text { Unit } \\
\text { mutation }\end{array}$}} & \multirow{2}{*}{\multicolumn{2}{|c|}{ Death }} & \multirow[t]{3}{*}{ Total } \\
\hline & & & \multicolumn{2}{|c|}{$\overline{\mathrm{MCO}}$} & \multicolumn{2}{|l|}{ SSR } & \multicolumn{2}{|c|}{ USLD } & \multicolumn{2}{|l|}{ Total } & & & & & \\
\hline & Stay & $\%$ & Stay & $\%$ & Stay & $\%$ & Stay & $\%$ & Stay & $\%$ & Stay & $\%$ & Stay & $\%$ & \\
\hline B020"HZ encephalitis" & 31 & $49.2 \%$ & 9 & $40.9 \%$ & 12 & $54.5 \%$ & 1 & $4.5 \%$ & 22 & $34.9 \%$ & 5 & $7.9 \%$ & 5 & $7.9 \%$ & 63 \\
\hline B021 "HZ meningitis" & 28 & $63.6 \%$ & 4 & $40.0 \%$ & 6 & $60.0 \%$ & 0 & $0.0 \%$ & 10 & $22.7 \%$ & 5 & $11.4 \%$ & 1 & $2.3 \%$ & 44 \\
\hline B022 "HZ with neurological disease" & 356 & $79.1 \%$ & 14 & $29.8 \%$ & 31 & $66.0 \%$ & 2 & $4.3 \%$ & 47 & $10.4 \%$ & 39 & $8.7 \%$ & 8 & $1.8 \%$ & 450 \\
\hline B023 "HZ Ophtalmicus" & 398 & $81.7 \%$ & 18 & $33.3 \%$ & 32 & $59.3 \%$ & 4 & $7.4 \%$ & 54 & $11.1 \%$ & 25 & $5.1 \%$ & 10 & $2.1 \%$ & 487 \\
\hline B027 "Disseminated HZ" & 118 & $80.3 \%$ & 7 & $41.2 \%$ & 9 & $52.9 \%$ & 1 & $5.9 \%$ & 17 & $11.6 \%$ & 9 & $6.1 \%$ & 3 & $2.0 \%$ & 147 \\
\hline B028 "HZ with other complications" & 372 & $79.3 \%$ & 18 & $35.3 \%$ & 32 & $62.7 \%$ & 1 & $2.0 \%$ & 51 & $10.9 \%$ & 40 & $8.5 \%$ & 6 & $1.3 \%$ & 469 \\
\hline B029 "HZ with no complications" & 757 & $83.1 \%$ & 33 & $37.5 \%$ & 51 & $58.0 \%$ & 4 & $4.5 \%$ & 88 & $9.7 \%$ & 61 & $6.7 \%$ & 5 & $0.5 \%$ & 911 \\
\hline$\%$ Sub-Total & & & & $35.6 \%$ & & $59.9 \%$ & & $4.5 \%$ & & $100 \%$ & & & & & \\
\hline Total & 2,060 & $80.1 \%$ & 103 & $4.0 \%$ & 173 & $6.7 \%$ & 13 & $0.5 \%$ & 289 & $11.2 \%$ & 184 & $7.2 \%$ & 38 & $1.5 \%$ & 2,571 \\
\hline
\end{tabular}

HZ: Herpes Zoster, LOS: Length of Stay, MCO: Medicine Surgery Obstetrics, SSR: After-care and rehabilitation, USLD: Long-Term Care Unit 
immunosuppression factors were identified in the 2011 PMSI database. Of the hospital stays with a zona comorbidity, only 1,717 hospital stays were selected corresponding to the 5 main reasons of hospitalizations : circulatory (ICD-10 codes: $\mathrm{I}^{*}-\mathrm{I}^{*} \& \mathrm{I} 7^{*}-\mathrm{I} 9^{*}$ ), respiratory $\left(\mathrm{J}^{*}-\mathrm{J} 9^{*}\right)$, osteoarticular $\left(\mathrm{M} 0^{*}-\mathrm{M} 9^{*}\right)$, digestive systems $(\mathrm{K} 0 *-\mathrm{K} 9 *)$, and diabetes $(\mathrm{E} 1 *)$. In order to evaluate the statistical impact of zona as comorbidity on length of stay, death rate, and cost, a separately case control was performed for each disease.

Chi-square tests showed that age and sex distribution were significantly different between the 2 cohorts for each disease $(\mathrm{p}<0.001)$. As a consequence, extracted data were adjusted by age and sex for all disease [Table 4]. A case-cohort stay was matched with 3 randomly chosen control-cohort stays for the same age group, sex and pathology. The co-morbidity analysis was based on the selection of the 1.717 stays for patients aged over 50 years in cases cohort and of 5,151 stays out of the 3,665,088 stays of patients aged over 50 years in control cohort [Table 4].

\section{$\mathrm{HZ}$ impact as co-morbidity in 5 main diseases}

In each of the five diseases, i.e. circulatory, respiratory, osteoarticular system, digestive systems and diabetes, the median LOS presented a statistically significant difference between cases and control cohorts [Table 5]. For osteoarticular system, the median LOS differed by 3 days leading to a $50 \%$ rise from control cohort to cases cohort. The median LOS differed by 4 days $(+80 \%)$ for diabetes and by 5 days $(+71 \%)$ for respiratory system. Then, the median LOS differed by 6 days for circulatory system $(+120 \%)$ and for digestive system $(+300 \%)$.

Statistically significant difference in median stay costs were demonstrated between cases and control cohorts [Table 5]. For circulatory system, median stay costs differed by $857 €$ ( $25 \%$ rise in the case cohort compared to controls). Median stay costs differed by $922 €(+26 \%)$, from $945 €(+26 \%)$ and from $987 €(+39 \%)$ for osteoarticular system, for respiratory system and for diabetes respectively. Then, the median hospital stay costs differed by $2,011 €$ for digestive system $(+126 \%)$.

No difference was observed in the death rates in 3 diseases: circulatory system, respiratory system and diabetes [Table 5]. Death rates for osteoarticular system varied for the 3 age groups: it was identical in both cohorts of [50-75] years groups; null in both cohorts of [75-85] years groups and significantly different $(1.86 \%$ for cases cohort and $0.24 \%$ for control cohort) in the group of 85 years and over group.

\section{Discussion}

The current PMSI 2011 analysis identified 2,571 stays of patients aged over 50 years hospitalized for HZ corresponding of $0.9 \%$ of the 2011 recorded total stays, while diabetes represented 95,204 stays (62 times more) and degenerative disease represented 48,291 stays (19 times more). The HZ represents a subsequent economic burden of approximately

Table 4 Data classification per hospitalization causes, ages, and sex

\begin{tabular}{|c|c|c|c|c|c|c|c|c|c|}
\hline & & & Cases $^{a}$ & & Total & & Controls $^{\mathrm{b}}$ & & Total \\
\hline & & {$[50-75]$} & [75-85] & $\begin{array}{l}\text { [85 years } \\
\text { and over] }\end{array}$ & & {$[50-75]$} & [75-85] & $\begin{array}{l}\text { [85 years } \\
\text { and over] }\end{array}$ & \\
\hline \multirow[t]{3}{*}{ Circulatory System } & Men & 81 & 89 & 62 & 232 & 243 & 267 & 186 & 696 \\
\hline & Women & 57 & 133 & 193 & 383 & 171 & 399 & 579 & 1,149 \\
\hline & Total & 138 & 222 & 255 & 615 & 414 & 666 & 765 & 1,845 \\
\hline \multirow[t]{3}{*}{ Respiratory System } & Men & 86 & 89 & 73 & 248 & 258 & 267 & 219 & 744 \\
\hline & Women & 59 & 89 & 85 & 233 & 177 & 267 & 255 & 699 \\
\hline & Total & 145 & 178 & 158 & 481 & 435 & 534 & 474 & 1,443 \\
\hline \multirow[t]{3}{*}{ Osteo-articular System } & Men & 44 & 30 & 15 & 89 & 132 & 90 & 45 & 267 \\
\hline & Women & 62 & 51 & 66 & 179 & 186 & 153 & 198 & 537 \\
\hline & Total & 106 & 81 & 81 & 268 & 318 & 243 & 243 & 804 \\
\hline \multirow[t]{3}{*}{ Digestive System } & Men & 44 & 29 & 20 & 93 & 132 & 87 & 60 & 279 \\
\hline & Women & 71 & 64 & 47 & 182 & 213 & 192 & 141 & 546 \\
\hline & Total & 115 & 93 & 67 & 275 & 345 & 279 & 201 & 825 \\
\hline \multirow[t]{3}{*}{ Diabetes } & Men & 23 & 13 & 2 & 38 & 69 & 39 & 6 & 114 \\
\hline & Women & 8 & 20 & 12 & 40 & 24 & 60 & 36 & 120 \\
\hline & Total & 31 & 33 & 14 & 78 & 93 & 99 & 42 & 234 \\
\hline Total & & 535 & 607 & 575 & 1,717 & 1,605 & 1,821 & 1,725 & 5,151 \\
\hline
\end{tabular}

${ }^{a}$ Cohort of patients hospitalized with $\mathrm{HZ}$ as comorbidity

${ }^{\mathrm{b}}$ Cohort of patients hospitalized without $\mathrm{HZ}$ comorbidity 
Table $\mathbf{5} \mathrm{HZ}$ as co-morbidity analyses: LOS, death rate and economic evaluation

\begin{tabular}{|c|c|c|c|c|c|c|}
\hline & & Circulatory system & Respiratory system & Osteoarticulary system & Digestive system & Diabetes \\
\hline \multicolumn{7}{|l|}{ LOS } \\
\hline \multirow[t]{2}{*}{ Median (days) } & Cases $^{\mathrm{a}}$ & 11 & 12 & 9 & 8 & 9 \\
\hline & Control $^{b}$ & 5 & 7 & 6 & 2 & 5 \\
\hline Median difference days & & 6 & 5 & 3 & 6 & 4 \\
\hline$\%$ rise & & $1.2 \%$ & $0.71 \%$ & $0.5 \%$ & $3 \%$ & $0.8 \%$ \\
\hline Tests (Wilcoxon-Mann-Whitney) & ( $p$ values 0,05 ) & $<0.0100$ & $<0.0001$ & $<0.0001$ & $<0.0001$ & $<0.0001$ \\
\hline \multicolumn{7}{|l|}{ Death rate } \\
\hline \multicolumn{7}{|l|}{ Deaths among cases cohort ${ }^{\mathrm{a}}$} \\
\hline & Death rate (\%) & $32 / 615$ & $41 / 481$ & $5 / 268$ & $16 / 275$ & $1 / 78$ \\
\hline \multirow[t]{2}{*}{ Deaths among control cohort ${ }^{\mathrm{b}}$} & & $5.2 \%$ & $8.52 \%$ & $1.86 \%$ & $5.81 \%$ & $1.28 \%$ \\
\hline & Death rate (\%) & $113 / 1,845$ & $155 / 1,443$ & $2 / 804$ & $26 / 825$ & $3 / 234$ \\
\hline Chi-square probability & ( $p$ value 0,05 ) & $6.12 \%$ & $10.74 \%$ & $0.24 \%$ & $3.15 \%$ & $1.28 \%$ \\
\hline \multicolumn{7}{|l|}{ Hospital stay cost } \\
\hline \multirow[t]{2}{*}{ Median (€) } & Cases cohort ${ }^{\mathrm{a}}$ & 4,228 & 4,534 & 4,475 & 3,601 & 3,510 \\
\hline & Control cohort ${ }^{b}$ & 3,371 & 3,589 & 3,553 & 1,590 & 2,523 \\
\hline Median difference $(€)$ & & 857 & 945 & 922 & 2,011 & 987 \\
\hline$\%$ rise & & $25 \%$ & $26 \%$ & $26 \%$ & $126 \%$ & $39 \%$ \\
\hline Tests (Wilcoxon-Mann-Whitney) & ( $p$ value 0,05 ) & $<0.0100$ & $<0.0001$ & $<0.0001$ & $<0.0001$ & $<0.0001$ \\
\hline
\end{tabular}

HZ: Herpes Zoster

LOS: Length of stay

${ }^{a}$ Cohort of patients hospitalized with $\mathrm{HZ}$ in $\mathrm{SAD}$

${ }^{\mathrm{b}}$ Cohort of patients hospitalized without $\mathrm{HZ}$ in SAD

11 million€ in global Health Assurance expenses and quality management may reduce the total amount spent for $\mathrm{HZ}$ treatment. The total annual costs of B029 "HZ without complications" and B023 "Zoster Ocular Disease" care were responsible for $29 \%$ and $16 \%$ of total $\mathrm{HZ}$ annual costs respectively. The HZ stay mean cost is $4,206 €$ ranging between 3,480€ for $\mathrm{HZ}$ without complications to $8,893 €$ for Zoster encephalitis. The Zoster Ocular Disease stay mean cost of 3,516€ is similar to the cost observed in $\mathrm{HZ}$ without complications. The absence of cost impact between these two $\mathrm{HZ}$ is due to the classification DRG system. In the case of Zoster Ocular Disease stays, the DRG are mainly distributed in the Major Diagnostic Category (MDC) 02 therefore the $\mathrm{HZ}$ without complications stays are mainly distributed in the MDC 09. The DRG tariffs relevant to the MDC 02 are lower than the DRG tariffs of MDC 09.

Clinical and costs input data were derived from a cohort of 2,392 patients, with $60 \%$ of women and with a mean age of 76.3 years. Death occurs in $1.6 \%$ of cases of patients hospitalized with zoster. B020 "HZ encephalitis" and B021 "HZ meningitis" stays characteristics involved older patients, longer LOS, higher rates of transfer to another health care institution and higher death rates even though the related number of extracted stays was the lowest (63 and 44 stays respectively).

When present as only comorbidity in hospitalizations for other hospitalization causes, $\mathrm{HZ}$ significantly increases the LOS at hospital and subsequent economic burden for the French health system whereas death rates were not linear as expected and do not stand a classical conclusion. Comorbidity indicates the co-occurrence of preexisting age-related health conditions in reference to an index disease [27]. Advanced age is associated with increased vulnerability to chronic health problems. Given the complexity and heterogeneity involved in comorbidity, however, no single definition or measure would serve all research and clinical purposes. The level of comorbidity correlates with the magnitude of immune response in older adults (decrease in T cell proliferation and IL-12 production and increase in IL-10 production in response to PHA stimulation) [28]. Until recent published papers, comorbidities were not taken into account in the management and prognosis of herpes zoster [29]. Risk of herpes zoster has been found in patients with chronic obstructive pulmonary disease [30], kidney disease [31, 32], rheumatoid arthritis [33], inflammatory bowel disease [34], type II diabetes [35]. In addition, some authors report a risk of cancer after infection by herpes zoster [36, 37]. Few data analyzed impact of comorbidities on the management and the cost of herpes zoster.

A Spanish study has been conducted by Gil-Prieto et al. in 2011, describing the disease burden of patients aged $\geq 50$ years hospitalized with HZ (in DP or DAS) between 
1998 and 2004 who presented Chronic Obstructive Pulmonary Disease (COPD), cardiovascular disease and/or diabetes [38]. The annual number of hospitalization was 2,289 stays with a mean LOS of 12.4 days. Death rates were $3.7 \%$ and increased to $4.7 \%$ for patients with comorbidity even though death rates were $2.1 \%$ for the cohort without comorbidities. Death rates were higher due to a higher death probability in the treatment of COPD, cardiovascular disease and/or diabetes as the cohort involved patients hospitalized for another primary diagnosis (COPD, cardiovascular disease and/or diabetes).

The study shows only than more women than men with $\mathrm{HZ}$ are hospitalized and hospitalization is prevalent in older ages, which is in line with epidemiological studies. As reported by Gonzalez Chiappe et al. [20] and by Chang et al. two decades ago for an Asian population [39], the predominance of $\mathrm{HZ}$ in women might be ascribed to a higher proportion of females in the older population. Moreover, Thomas et al. added, in 2004, that women might be more likely to seek medical advice, thereby causing higher reporting rate [32]. Pinchinat et al. review stated, in 2013, that HZ incidence increases sharply with age for the European population [12, 40].

The present study method included a check step by analyzing the age and sex characteristics and their statistical differences in both groups with $\mathrm{HZ}$ and without $\mathrm{HZ}$ in each of the five pathologies. This check step conclusion determined the need of matching for further analyses to neutralize the confounding factors.

This study highlighted the impact of an associated diagnosis of $\mathrm{HZ}$ for patients aged 50 years and older with chronic conditions. When associated to one of the 5 most common chronic diseases, HZ significantly increased the LOS. Herpes Zoster significantly increases length of hospitalization $(\mathrm{p}<0.001)$ leading to subsequent economic burden for the French health system. It is expected that this extension of LOS also has an impact on the cost of the management of the disease. Herpes Zoster doesn't significantly increase the number of deaths.

This review has various limitations. First of all, PMSI database is the basis of hospital funding and not an epidemiological register. The prospective payment is directly linked to the coding process leading to optimize this latter. Nevertheless the high exhaustiveness and quality of information (including some medical information) allows using the PMSI database to estimate various indicators by disease, like the number of patients hospitalized annually, the number of stays per patient and the total cost of hospitalization [24-26]. Using hospitals and death records generate limitations: codes were not necessarily accurate; i.e., misclassification or diagnosis errors by coding as a different herpes [41], under reporting of pre-existing conditions such as stroke
[42]; inadvertent omissions, the unavailability of medical records to certifying physician and difficulties in determining the underlying cause of death and hospitalization when several disease processes were involved [43, 20].

Further investigations to study the impact of $\mathrm{HZ}$ comorbidty in other categories, to provide up-to-date analyses (PMSI 2013 follow-up) in the following 5 to 10 years, will allow a long-term projection of clinical characteristics, economic evaluation and trend over time.

\section{Conclusion}

The present study evaluated the economic burden of $\mathrm{HZ}$ as the cause of hospitalization and as comorbidity. The total annual cost of $\mathrm{HZ}$ as cause of hospitalization was approximately 11 millions $€$ and the mean costs per stay was $4,206 €($ SD 6,711€). About a third (29\%) of the annual cost was explained by the B029 "HZ with no complications".

When HZ was present as only comorbidity in five hospitalizations reasons (circulatory system, respiratory system, osteoarticular system, digestive system and diabetes), the hospitalizations length of stay and cost were significantly increased $(\mathrm{p}<0.001)$. Median stay costs rose from $25 \%$ to $126 \%$ and median LOS from 3 to 6 days.

In a context of ageing population, where incidence of $\mathrm{HZ}$ increases dramatically after 50 years of age, $\mathrm{HZ}$ impact length of stay and contributes to demonstrating the clinical and economic impact of HZ. The hospitalization economic burden is only a part of the total cost of management of $\mathrm{HZ}$.

\section{Abbreviations}

ATIH: Agence Technique de I'Information sur l'Hospitalisation; CCAM: French Classification Of Medical Procedures or Classification Commune des Actes Médicaux; CNIL: National commission for data processing and civil liberties; COPD: Chronic Obstructive Pulmonary Disease; DAS: Secondary Associated Diagnosis or Diagnostic Associé Significatif; DIM: Department Of Medical Data or Département d'Information Médicale; DR: Associated Diagnosis or Diagnostic Relié; ENCC: National study of costs or Echelle Nationale des Coûts à Méthodologie Commune; HZ: Herpes Zoster; ICD-10: $X^{\text {th }}$ Revision of the International Classification of Diseases; INPES: French Institute for Health Education and Prevention; INSEE: French Institute For Statistics And Economic Studies; LOS: Length of Stay; PMSI-MCO: French Computerised Hospital Database For Medicine, Surgery And Obstetrics or Programme de Médicalisation des Systèmes d'Information-Médecine Chirurgie Obstétrique; MDC: Major Diagnostic Category; PD: Principal Diagnosis or Diagnostic Principal; PY: person-years; RSA: Discharge Summary or Résumé de Sortie Anonyme; SSR: Recovery Center or Soin de Suite et de Réadaptation; T2A: Prospective Payment or Tarification à l'Activité; USLD: Long-Term Unit Care or Unité de Soins de Longue Durée; VZV: Varicella-Zoster Virus.

\section{Competing interests}

This study was supported by an unrestricted grant from SP MSD. Charles Baptiste is an employee of Sanofi Pasteur. Cécile Blein is an employee of HEVA, who were contracted by Sanofi Pasteur to participate in this study. Alexandre Vainchtock is the CEO of HEVA who was contracted by Sanofi Pasteur to participate in this study. 
Gaetan Gavazzi has already acted as a consultant, orator or advisory board for Pfizer/ BioMérieux, Sanofi-Pasteur MSD: Sanofi-Pasteur MSD, Pfizer, ViforPharma,Novartis, AstraZeneca.

Gilles Berrut has already worked for Sanofi Pasteur MSD.

Marc Paccalin has never directly received fees from Sanofi Pasteur MSD.

\section{Authors' contributions}

CB participated in the design of the study, performed the statistical analysis and drafted the manuscript. GG, MP, BC, GB and AV participated in the design and coordination and helped to draft the manuscript of the study. All authors read and approved the final manuscript.

\section{Acknowledgements}

The authors kindly acknowledge SP MSD for its support in the analysis conduct, the DIM physician, Dr. J. FERNANDEZ who brought his expertise in the hospital coding management and Maëlle DELEGLISE, HEVA HEOR, for the medical writing support.

\section{Author details}

${ }^{1}$ HEVA, Lyon, France. ${ }^{2}$ Université de Grenoble-Alpes et GREPI, clinique universitaire de médecine gériatrique, $\mathrm{CHU}$ de Grenoble, la tronche, France. ${ }^{3}$ Geriatrics Department University Hospital La Milétrie, Poitiers, France. ${ }^{4}$ Sanofi Pasteur MSD, Lyon, France. ${ }^{5}$ Hôpital Saint Jacques, CHU de Nantes, Nantes, France.

\section{Received: 24 November 2014 Accepted: 23 July 2015}

\section{Published online: 19 August 2015}

\section{References}

1. Dworkin RH, Johnson RW, Breuer J, Gnann JW, Levin MJ, Backonja M, et al. Recommendations for the management of Herpes Zoster. Clin Infect Dis. 2007:44(Supplement 1):S1-S26.

2. Wallace MS, Oxman MN. Acute herpes zoster and postherpetic neuralgia. Anesthesiology Clinics of North America. 1997;2(13):371-405.

3. Sampathkumar P, Drage LA, Martin DP. Herpes zoster (shingles) and postherpetic neuralgia. Mayo Clin Proc Mayo Clin. 2009;84(3):274-80.

4. Forbes HJ, Bhaskaran K, Thomas SL, et al. Quantification of risk factors for herpes zoster: population based case-control study. BMJ. 2014;348:g2911. doi:10.1136/bmj.g2911.

5. Shingles (Herpes Zoster) Clinical Overview. Centers Dis. Control Prev. 2012. http:// www.cdc.gov/shingles/hcp/clinical-overview.html (assessed on 17 august 2015)

6. Oxman MN, Levin MJ, Johnson GR, Schmader KE, Straus SE, Gelb LD, et al. A vaccine to prevent herpes zoster and postherpetic neuralgia in older adults. $\mathrm{N}$ Engl J Med. 2005:352(22):2271-84.

7. Nagasako EM, Johnson RW, Griffin DRJ, Dworkin RH. Rash severity in herpes zoster: correlates and relationship to postherpetic neuralgia. J Am Acad Dermatol. 2002;46(6):834-9.

8. Yawn BP, Saddier P, Wollan PC, St Sauver JL, Kurland MJ, Sy LS. A populationbased study of the incidence and complication rates of herpes zoster before zoster vaccine introduction. Mayo Clin Proc. 2007:82(11):1341-9.

9. Yawn BP, Wollan PC, St. Sauver JL, Butterfield LC. Herpes zoster Eye complications: rates and trends. Mayo Clin Proc. 2013:88(6):562-70.

10. Schiffner-Rohe J, Jow S, Lilie HM, Köster I, Schubert I. Herpes zoster in Germany. A retrospective analyse of SHL data. MMW Fortschr Med. 2010;151 Suppl 4:193-7.

11. Helgason S, Sigurdsson JA, Gudmundsson S. The clinical course of herpes zoster: a prospective study in primary care. Eur J Gen Pr. 1996;2(1):12-6.

12. Pinchinat S, Cebrián-Cuenca AM, Bricout H, Johnson RW. Similar herpes zoster incidence across Europe: results from a systematic literature review. BMC Infect Dis. 2013:13:170

13. Kawai K, Gebremeskel BG, Acosta CJ. Systematic review of incidence and complications of herpes zoster: towards a global perspective. BMJ Open. 2014;4:e004833. doi:10.1136/bmjopen-2014-004833.

14. Rimland D, Moanna A. Increasing incidence of herpes zoster among veterans. Clinical Infectious Diseases. 2010;50:1000-5.

15. Yawn BP, Wollan PC, Kurland MJ, St. Sauver JL, Saddier P. Herpes zoster recurrences more frequent than previously reported. Mayo Clin Proc. 2011;86(2):88-93.

16. Réseau Sentinelles. Bilan annuel 2009 - Rapport d'activité. Paris; 2009 déc

17. Réseau Sentinelles. Bilan annuel 2010 - Rapport d'activité. Paris; 2010 déc.

18. Réseau Sentinelles. Bilan annuel 2011 - Rapport d'activité. Paris; 2011 déc.

19. Réseau Sentinelles. Bilan annuel 2012 - Rapport d'activité. Paris; 2012 déc.
20. Gonzalez Chiappe S, Sarazin M, Turbelin C, Lasserre A, Pelat C, Bonmarin I, et al. Herpes zoster: burden of disease in France. Vaccine. 2010;28(50):7933-8.

21. Riou C, Rouget F, Sinteff J, et al. Outil de contrôle d'exhaustivité des cas pour le registre des malformations congénitales de Bretagne à partir des données PMSI. Journées EMOIS Nancy. 2013

22. Buisson $\mathrm{G}$. Redressement du Programme de médicalisation des systèmes d'informations (PMSI). Direction de la recherche, des études, de l'évaluation et des statistiques; 2005 Mar 1. Report No.: 80.

23. Haut conseil de la Santé Publique. Les systèmes d'information pour la santé publique. November 2009. [http://www.ladocumentationfrancaise.fr/rapportspublics/104000182/index.shtml] (Accessed august 2015).

24. Quantin C, Cottenet J, Vuagnat A, Benzenine E, Fresson J, Prunet C, et al. Validité des données périnatales issues du pmsi: comparaison avec les données de l'enquête nationale périnatale 2010. Rev Epidemiol Sante Publique. 2013;61:S6.

25. Bernier M-O, Mezzarobba M, Maupu E, Caër-Lorho S, Brisse HJ, Laurier D, et al. Role of French hospital claims databases from care units in epidemiological studies: the example of the « Cohorte Enfant Scanner » study. Rev Epidemiol Sante Publique. 2012;60(5):363-70.

26. Hafdi-Nejjari Z, Couris C-M, Schott A-M, Schot A-M, Perrot L, Bourgoin F, et al, Role of hospital claims databases from care units for estimating thyroid cancer incidence in the Rhône-Alpes region of France. Rev Epidemiol Sante Publique. 2006:54(5):391-8.

27. Yancik R, Ershler W, Satariano W, Hazzard W, et al. Comorbidity: the ultimate geriatric syndrome: report of the National Institute on Aging Task Force on Comorbidity. J Gerontol A Biol Sci Med Sci. 2007;62(3):275-80.

28. Castle SC, Uyemura K, Rafi A, Akande O, Makinodan T. Comorbidity is a better predictor of impaired immunity than chronological age in older adults. J Am Geriatr Soc. 2005;53:1565-9.

29. Thomas SL, Hall AJ. What does epidemiology tell us about risk factors for herpes zoster? Lancet Infect Dis. 2004:4(1):26-33.

30. Yang YW, Chen YH, Wang KH, Wang CY, Lin HW. Risk of herpes zoster among patients with chronic obstructive pulmonary disease: a population-based study. CMAJ. 2011;183(5):E275-80.

31. Wu MY, Hsu YH, Su CL, Lin YF, Lin HW. Risk of herpes zoster in CKD: a matched-cohort study based on administrative data. Am J Kidney Dis. 2012;60(4):548-52.

32. Kuo CC, Lee CT, Lee IM, Ho SC, Yang CY. Risk of herpes zoster in patients treated with long-term hemodialysis: a matched cohort study. Am J Kidney Dis. 2012;59(3):428-33.

33. McDonald JR, Zeringue AL, Caplan L, Ranganathan P, Xian H, Burroughs TE, et al. Herpes zoster risk factors in a national cohort of veterans with rheumatoid arthritis. Clin Infect Dis. 2009;48(10):1364-71.

34. Gupta G, Lautenbach E, Lewis JD. Incidence and risk factors for herpes zoster among patients with inflammatory bowel disease. Clin Gastroenterol Hepatol. 2006:4(12):1483-90

35. Guignard AP, Greenberg M, Lu C, Rosillon D, Vannappagari V. Risk of herpes zoster among diabetics: a matched cohort study in a US insurance claim database before introduction of vaccination, 1997-2006. Infection. 2014:42:729-35.

36. Cotton SJ, Belcher J, Rose P, Jagadeesan KS, Neal RD. The risk of a subsequent cancer diagnosis after herpes zoster infection: primary care database study. $\mathrm{Br} \mathrm{J}$ Cancer. 2013;108(3):721-6.

37. Chiu HF, Chen BK, Yang CY. Herpes zoster and subsequent risk of cancer: a population-based study. J Epidemiol. 2013;23(3):205-10.

38. Gil-Prieto R, San Martín M, de Andrés AL, Alvaro-Meca A, González A, de Miguel AG. Herpes zoster hospitalizations of patients with chronic illnesses in Spain 1998-2004. Vacunas. 2011;12(3):95-101.

39. Chang CM, Woo E, Yu YL, Huang CY, Chin D. Herpes zoster and its neurological complications. Postgrad Med J. 1987;63(736):85-9.

40. Volpi A, Gross G, Hercogova J, Johnson RW. Current management of herpes zoster: the European view. Am J Clin Dermatol. 2005;6(5):317-25.

41. Sawyer AR, Williams G. Misdiagnosis of burns: herpes zoster ophthalmicus. J Burn Care Res. 2006;27(6):914-6.

42. Lin H-C, Chien C-W, Ho J-D. Herpes zoster ophthalmicus and the risk of stroke: a population-based follow-up study. Neurology. 2010;74(10):792-7.

43. Gauthier A, Breuer J, Carrington D, Martin M, Rémy V. Epidemiology and cost of herpes zoster and post-herpetic neuralgia in the United Kingdom. Epidemiol Infect. 2009;137(1):38-47. 